\title{
Deteksi Sederhana Boraks dan Formalin pada Makanan Jajanan Anak dengan Bunga Terompet Ungu (Ruellia Tuberosa)
}

\author{
Rini Tri Hastuti ${ }^{1 *}$, Youstiana Dwi Rusita ${ }^{2}$ \\ ${ }^{1,2}$ Jurusan Anafarma, Poltekkes Kemenkes Surakarta \\ *Email: rini_trihastuti@yahoo.com
}

\begin{abstract}
Background: Borax and Formalin are often misused by naughty producers as additional preservatives in children's snacks such as cilok, meatballs, noodles and other foods. BPOM data shows that throughout 2012, the incidence of poisoning due to consuming food occupied the highest position, namely 66.7\%, one of the causes of food poisoning was the presence of chemical contamination in children's snack foods, such as borax and formalin. The accumulation of these substances in the body can have a negative impact on health. Purple trumpet flower is a simple detection material to find out the presence of borax and formalin in food. The aim of community service is to increase knowledge in mothers of school-age children, how to detect simple borax and formalin in children's snacks with purple trumpet flowers. Methods: The method by means of detection training is how to detect simple borax and formalin in children's snacks with purple trumpet flowers. Results: From the results of community service, that mothers with $90 \%$ of school-age children can do a simple way of detecting borax and formalin in children's snacks with purple trumpet flowers. Conclutions: that mothers of school-age children can do a simple way of detecting borax and formalin in children's snacks with purple trumpet flowers.
\end{abstract}

Keywords: children's snack, borax and formalin, purple trumpet flowers

\section{PENDAHULUAN}

Usia sekolah adalah masa tumbuh kembang anak menginjak usia remaja, oleh karena itu pemberian gizi cukup serta keamanan pangan yang akan dikonsumsi sangatlah penting, begitu juga jajanannya. Sekitar 99\% anak di usia sekolah membeli jajanan di sekolah guna mencukupi energinya ketika di sekolah. Pengawasan yang dilakukan oleh BPOM tahun 2008-2010 menyatakan bahwa 40-44\% sampel jajanan anak sekolah yang telah diuji, tidak memenuhi persyaratan dikarenakan penyalahgunaan bahan tambahan pangan berbahaya serta cemaran mikroba yang melebihi batas. Permasalahan ini membuktikan kurangnya wawasan, kesadaran, dan kepedulian para pembuat, penjual, dan pembeli pada pentingnya keamanan pangan (BPOM, 2014).

Pangan yang aman merupakan hal yang perlu diperhatikan karena berdampak pada kesehatan anak. Data dari BPOM, pada tahun 2012, kasus keracunan yang diakibatkan karena mengonsumsi makanan mendapat perolehan tertinggi, yaitu $66,7 \%$, jika dibandingkan kasus keracunan akibat penyebab lain, seperti obat, minuman herbal, kosmetika, dan lain-lain. Penyebab keracunan makanan saah satunya dikarenakan kandungan bahan tambahan pangan seperti boraks, pewarna tekstil dan formalin pada makanan (Paratmantya dan Aprilia, 2016).

Tahun 2011, BPOM melakukan pengujian laboratorium pada jajanan anak sekolah yang diambil dari 866 sekolah dasar/madrasah ibtidaiyah di 30 kota di Indonesia. Sampel jajanan yang diambil yaitu 4.808 sampel, $1.705(35,46 \%)$ dari sampel yang diuji di nyatakan tidak memenuhi syarat keamanan serta mutu pangan. 
Hasil pengujian pada bahan tambahan pangan yang dilarang, yaitu boraks dan formalin menggunakan sampel sebanyak 3.206 produk jajanan anak sekloah yaitu mie basah, bakso, dan makanan ringan, bahwa 94 (2,93\%) sampel mengandung boraks kemudian 43 (1,34\%) sampel mengandung formalin (BPOM, 2014).

Penggunaan boraks pada bahan pangan diperkuat oleh Permenkes RI No. 235/Menkes/VI/1984 tentang bahan tambahan makanan, boraks dikenal sebagai bahan tambahan yang dilarang ditambahkan pada makanan, namun kenyataannya penyalahgunaan dari zat tersebut masih banyak (Tubagus, 2013). Formalin dalam makanan dapat menyebabkan iritasi di membran mukosa serta bersifat racun (Wakefield, 2014), sering mengkonsumsi boraks dapat mengganggu gerak pencernaan usus, depresi, kekacauan mental ,dan kelainan pada susunan saraf (Saparinto, 2006). Mengonsumsi boraks pada makanan tidak langsung dapat berdampak buruk, yaitu boraks akan tertimbun sedikit-sedikit dalam organ otak, hati dan testis. Boraks terserap melalui pencernaan dan kulit. Boraks yang terserap tubuh dengan jumlah kecil dikeluarkan dalam bentuk air kemih, tinja, dan sedikit melalui keringat. Tak hanya mengganggu enzim-enzim metabolisme, namun borak juga mengganggu alat reproduksi pria (Nasution, 2009).

Indikator alami atau ramah lingkungan bisa dibuat dengan tumbuhan berwarna disekitar kita untuk deteksi borak dan formalin, tidak semua tumbuhan berwarna mampu menunjukkan perubahan warna yang jelas dengan kondisi asam atau basa, sehinggahanya beberapa tumbuhan berwarna yang bisa digunakan, misalnya bunga teropet ungu (Ruellia Tuberosa) yang dapat memberikan perubahan warna merah dalam suasana asam dan hijau dalam suasana basa, hal ini dikarenakan bunga teropet ungu mempunyai senyawa pemberi warna tumbuhan, yaitu antosianin. Senyawa antosianin digunakan sebagai pendeteksi adanya senyawa kimia seperti boraks dan formalin karena sifat asam dan basa akan bereaksi jika dicampur dengan antosianin (Nuryanti, dkk, 2010).

Temuan boraks dan formalin diberbagai jajanan di lingkungan sekolah beserta hasil investigasi media akibat penggunaan bahan makanan berbahaya pada jajanan hendaknya menjadi perhatian bersama. Berdasarkan permasalahan diatas perlu dilakukan kegiatan pengabdian masyarakat yaitu pelatihan deteksi sederhana kandungan borkas dan formalin pada makanan jajanan anak dengan bunga terompet ungu (ruellia tuberosa) bagi ibu dengan anak usia sekolah di Desa Trunuh, Kecamatan Klaten Selatan, Kabupaten Klaten.

Tujuan diadakannya kegiatan PKM ini adalah mencegah bahaya serta penyakit yang diakibatkan oleh bahan kimia berbahaya pada makanan dengan meningkatkan pengetahuan ibu dengan anak usia sekolah (6-12 tahun) tentang mendeteksi adanya formalin dan boraks dalam makanan jajanan anak dengan deteksi menggunakan alat sederhana bunga terompet ungu (ruellia tuberosa). Output kegiatan PKM adalah meningkatkan kesehatan masyarakat, serta meningkatan kesadaran masyarakat tetang memilih makanan jajanan anak yang aman, dan kemampuan ibu usia sekolah (6-12 tahun) tentang mendeteksi adanya formalin dan boraks dalam makanan jajanan anak dengan deteksi menggunakan alat sederhana bunga terompet ungu (ruellia tuberosa). 


\section{TINJAUAN PUSTAKA}

Anak sekolah merumakan anak usia 6-12 tahun, memiliki kekuatan fisik lebih, serta memiliki sifat individual yang aktif, dan tidak mengandalkan orang tua. Usia 6-12 tahun merupakan proses terjadi perubahan bervariasi pada pertumbuhan dan perkembangan anak dimana akan pembentukan karakteristik dan kepribadian. Usia sekolah menjadi pengalaman penting anak yang dianggap mampu bertanggung jawab atas tindakannya sendiri dalam hubungan pertemanan, orang tua dan lainnya. Usia sekolah juga merupakan fase dimana anak mendapat pengetahuan dasar dalam menentukan keberhasilan guna menyesuaikan diri dengan kehidupan dewasa serta mendapat keterampilan tertentu (Diyantini N. Yanti N. \& Lismawati S. 2015).

Jajanan sekolah yaitu makanan dan minuman yang dijajakan pedagang di area sekolah.. Jajanan tersebut biasanya langsung dikonsumsi tanpa ada pengolahan dan persiapan. Makanan jajanan biasa disebut dengan junk food, fast food, dan street food (Aprilia, 2011). Penelitian oleh Erniati (2017) bahwa berdasarkan uji laboratorium sampel bakso yang dijual di SD N Lemahputro III Sidoarjo, mayoritas positif mengandung boraks. Hal ini disebabkan pedagang bakso kurang mengetahui tentang pengertian, manfaat, dosis boraks yang diijinkan dan dampak dari boraks.

Hasil penelitian yang dilakukan Suhariyadi et al (2015) melaporkan bahwa pada jajanan siswa sekolah SD di Surabaya ditemukan adanya kandungan boraks sebesar 0,29\%. Meskipun ditemukan dengan kadar yang kecil namun hal ini perlu ditindaklanjuti dengan kontrol terhadap terhadap kualitas snack yang dikonsumsi siswa dengan memilih produsen makanan yang memproduksi makanan bebas boraks. Penelitian Ichya'uddin (2014) menunjukkan hasil dari 40 sampel yang ada di pasar tradisional wilayah Tuban, menyatakan $28(70 \%)$ sampel diantaranya positif formalin termasuk 28 sampel ikan asin. Produsen ikan menambahkan formalin untuk membantu mengawetkan ikan. Hasil penelitian menunjukkan kemungkinan paparan zat berbahaya seperti boraks dan formalin pada makanan, maka masyarakat sebagai konsumen diharapkan berhati-hati dalam memilih makanan.

Boraks sering digunakan dalam pembuatan plastik, detergen,pembasmi serangga, pembuatan antiseptik, glasi enamel gigi dan pengawet kayu. Formalin sejatinya, dipakai pada pembuatan kosmetik, desinfektan kua, perabot kayu, dan pengawet pada mayat. Boraks dengan dosis tinggi apabila dikonsumsi menyebabkan keracunan sel tubuh seperti kerusakan ginjal, hati, usus dan otak. Apabila jangka panjang dikonsumsi, menyebabkan kerusakan kanker dan hati. Dampak buruk boraks dalam jangka waktu panjang, akan terakumulasi dalam tubuh, dengan efek samping seperti mual, muntah, pusing, diare, kejang, penurunan nafsu makan, ganguan pencernaan, deman, anuria dan koma. Boraks dengan berat 5 gram pada anak kecil dapat menyebabkan kematian. Tampilan secara visual makanan mengandung boraks serta formalin tidak akan berbeda. Makanan yang mengandung boraks dan formalin mempuanyai ciri-ciri: hancur, sangat renyah, kenyal, berwarna 
lebih mencolok, tahan lebih dari tiga hari (tidak busuk dan berjamur), dan juga tidak dikerubungi oleh lalat dan semut (Dina M, 2019).

Konsumsi formalin dalam jangka panjang menyebabkan iritasi membran mukosa, radang kulit merangsang SPP, apatis, depresi, slanosis, pingsan, kebodohan dan bersifat racun (karsinogenik) (Walefield, 2014), konsumsi boraks secara kronis mengganggu kontraksi pencernaan usus, gangguan pada susunan saraf, depresi, dan kekacauan mental (Saparinto, 2005). Penggunaan boraks dalam dosis yang rendah tidak akan menyebabkan kerusakan namun akan terakumulasi di otak, hati, lemak, dan ginjal (Anonim, 2006). Banyaknya pedagang yang sudah menyadari akan bahaya Boraks dan juga Pemerintah yang sudah melarang penggunaan boraks dan bilamana masih ada pedagang yang menggunakan boraks akan ditindak lanjuti dengan pidana 12 tahun Penjara (Widyaningsih \& Murtini, 2006) sehingga pedagang pun menggunakan keragenan sebagai pengganti boraks.

Deteksi boraks dan formalin dengan metode titrasi volumetrik, uji nyala api, dan analisis spektrofotometri, masing-masing metode mempunyai kekurangan dan kelebihan sehingga alternatif metode lain untuk menambah informasi tentang metode analisis boraks dan formalin yang mudah, murah, dan lebih cepat (Fadjar, 2017). Indikator merupakan bahan kimia yang mengubah warna larutan dengan perubahan $\mathrm{pH}$ setelah ditambahkan basa atau asam (Gupta, 2012). Indikator asam basa yang digunakan di laboratorium kimia adalah indicator sintesis, indicator sintesis memiliki karakteristik berupa trayek $\mathrm{pH}$ yang ditunjukkan dengan perubahan warna pada kondisi asam dan basa serta harga tetapan indikator, indicator sintesis yang terbatas menyebabkan pemakaianya dibatasi, selain itu, indicator sintesis harganya cukup mahal, serta menyebabkan polusi lingkungan (Nuryanti, dkk, 2010). Karena hal tersebut perlu dicari indicator alternatif (indicator alami) yang mudah diperoleh dan ramah lingkungan.

Indikator alamiah dapat dibuat dari berbagai tumbuhan berwarna yang berada disekitar lingkungan untuk deteksi borak dan formalin, namun tidak semua tumbuhan berwarna dapat memberikan perubahan warna yang jelas pada kondisi asam atau basa, contoh tumbuhan yang dapat digunakan adalah bunga teropet ungu (Ruellia Tuberosa) yang dapat memberikan perubahan pada suasana asam warna merah dan hijau pada suasana basa hal ini dikarenakan antara bunga teropet ungu terdapat senyawa yang memberikan warna pada tumbuhan, yakni sebagai antosianin. Antosianin dapat digunakan pendeteksi adanya senyawa kimia seperti boraks dan formalin karena sifat asam basa dan akan bereaksi jika dicampur dengan antosianin (Nuryanti, dkk, 2010).

Bunga teropet ungu (Ruellia Tuberosa) sangat mudah ditemukan diberbagai tempat, dipinggir jalan dan harganya murah, biasanya digunakan sebagai tanaman hias yang belum dimanfaatkan secara masimal. Bunga teropmet ungu berasal dari Meksiko, Karibia dan Amerika Selatan, mengandung pigmen antosianin. Zat antosianin ini memberi warna ungu pada bungaterompet ungu. Penelitian menggunakan zat antosianin yang sensitif pada derajat keasaman $(\mathrm{pH})$ lingkungan dengan ditandai perubahan warna. Antosianin pada bunga terompet ungu memiliki penanda warna: merah untuk $\mathrm{pH} \mathrm{1-3,} \mathrm{coklat-kemerahan} \mathrm{untuk} \mathrm{pH} 5-6$, coklat- 
kehijauan untuk pH 7-8, hijau untuk pH 9-11 dan kuning untuk pH 13-14 (Noval K, 2019).

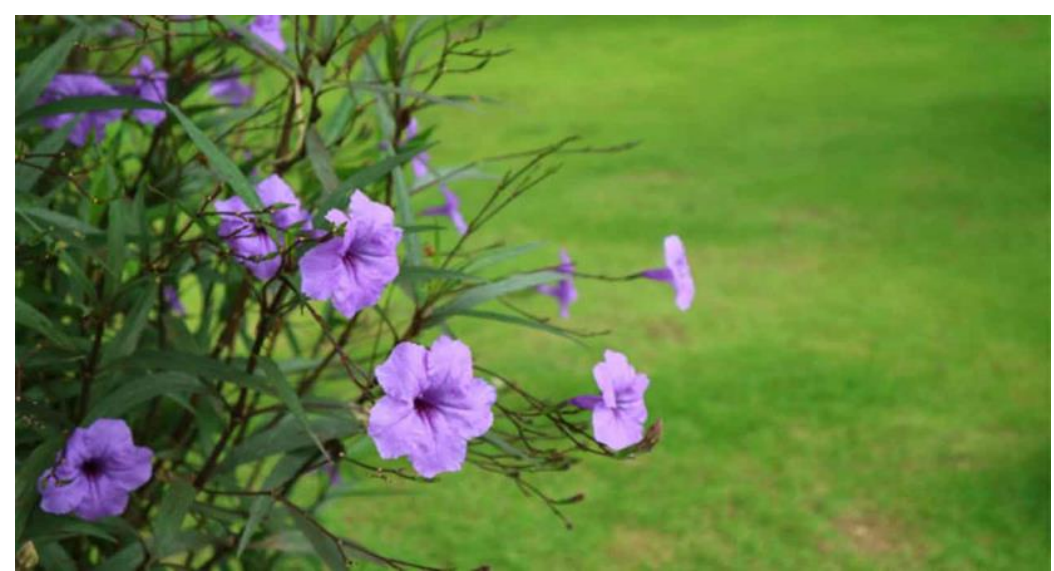

Gambar 1. Bunga Terompet Ungu (Ruellia Tuberosa)

Peneliti dari FK Universitas Indonesia (FKUI) menyarankan kepada masyarakat untuk selalu waspada dan deteksi kandungan boraks dan formalin pada makanan jajanan anak menggunakan bunga terompet ungu."Efek boraks dan formalin membahayakan kesehatan dan perkembangan otak pada anak. Penyalahgunaan boraks dan formalin meskipun sudahberkurag, namun sebagai orang tua tetap harus siap dan waspada," kata dr Ade Arsianti M.Si selaku Ketua Promgram Aksi UI di Jakarta. Deteksi sederhana boraks dan formalin mudah dilakukan dengan mengekstrak bunga terompet ungu dengan menumbuk sampai halus kemudian diberi sedikit air. Ekstrak bunga terompet ungu kemudian diteteskan pada sampel makanan yang juga dihaluskan dan ditambah sedikit air. Peralatan meliputi yaitu ulekan, pipet tetes/sedok teh, wadah berongga kecil seperti palet cat air, sampel makanan, air putih, dan beberapa bunga terompet ungu. Sampel makanan dihaluskan dan diberi sedikit air. Setiap sampel makanan diletakkan di rongga palet yang berbeda. Kemudian diberi label nama untuk mudah menandai dan mengidentifikasi makanan. Beberapa kuntum bunga terompet ungu dihaluskan dan diberikan sedikit air. Kemudian ambil beberapa tetes ekstrak bunga terompet ungu lalu diteteskan pada masing -masing sampel makanan yang di uji. Kemudian diamati perubahan warna pada sampel makanan yang di uji. Apabila sampel positif mengandung boraks warnanya akan menjadi hijau karena $\mathrm{pH}$ boraks sekitar 9-11. Sedangkan jika makanan positif mengandung formalin, warnanya akan menjadi coklat-kemerahan karena $\mathrm{pH}$ formalin sekitar 5-6. Makanan yang bebas formalin dan boraks akan berwarna ungu seperti warna asli ekstrak bunga terompet ungu (tidak mengalami perubahan warna). Perubahan warna yang terjadi sangat singkat beberapa menit sehingga langsung terlihat hasilnya (Dina M, 2019).

\section{METODE}

Sasaran kegiatan adalah ibu-ibu yang mempunyai anak usia sekolah (6 -12 tahun) di Desa Trunuh Kecamatan Klaten Selatan Kabupaten Klaten yang berjumlah 
60 orang. Pelaksanaan kegiatan Pengabmas dilakukan pukul 08.00-11.00 WIB di aula kantor kelurahan Desa Trunuh Kecamatan Klaten Selatan Kabupaten Klaten. Adapun pelaksanaan program kegiatan Pengabmas sebagai berikut :

a. Persiapan

Mempersiapkan alat dan bahan untuk pelatihan cara deteksi sederhana boraks dan formalin pada makanan jajanan anak dengan bunga terompet ungu :

1) Bunga terompet ungu beberapa kuntun

2) Ulekan

3) Pipet tetes atau sendok

4) Wadah berongga kecil seperti palet cat air

5) Sampel makanan (Cilok, Mie dan Sosis)

6) Gelas berisi air putih

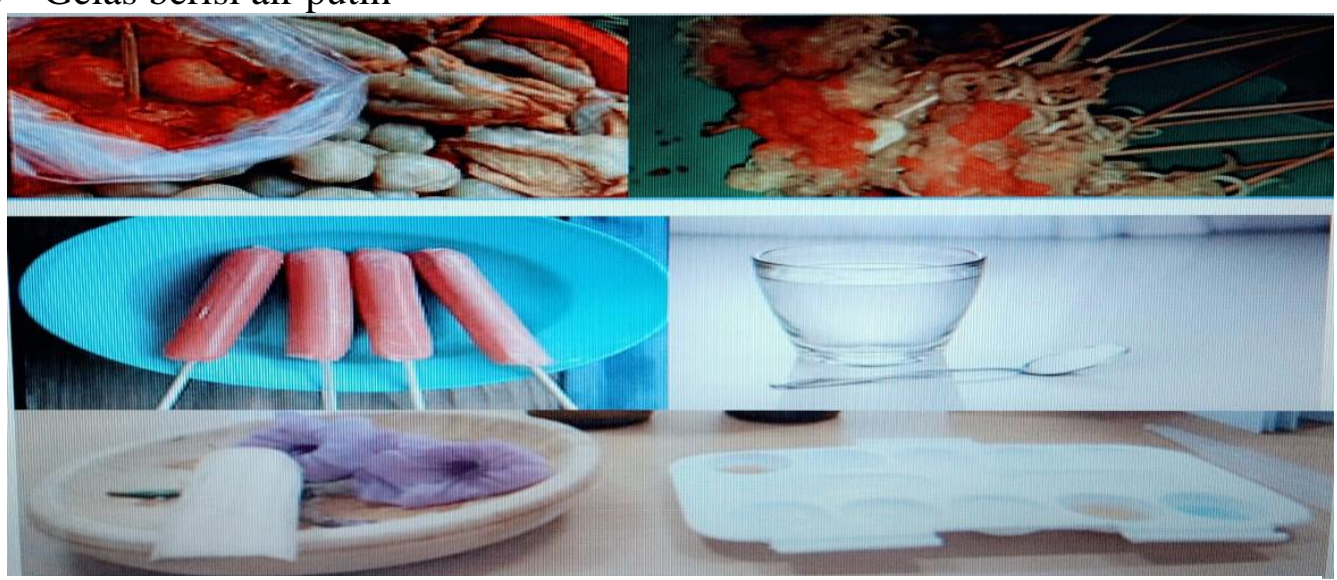

Gambar 2. Bahan dan Alat Deteksi Sederhana dengan Bunga Terompet Ungu

b. Penyuluhan kesehatan pada ibu dengan anak usia sekolah (6 - 12 tahun) untuk meningkatkan pengetahuan tentang bahan tambahan kimia pada makanan yang dilarang, bahaya, dampak dan cara untuk mendeteksi sederhana kandungan boraks dan formalin pada makanan janjanan anak dengan bunga terompet ungu. Peserta dijelaskan dan diberikan booklet yang berisi tentang materi yang sudah dijelaskan. Adapun tujuan diberikan booklet pada peserta adalah untuk dapat dibaca kembali materi penyuluhan yang sudah diberikan, lebih meningkatkan kemampuan dalam menyerap materi, mengaplikasikan cara untuk mendeteksi sederhana kandungan boraks dan formalin pada makanan janjanan anak dengan bunga terompet ungu peserta di rumah.

c. Pelaksanaan pelatihan cara deteksi sederhana kandungan boraks dan formalin pada makanan janjanan anak dengan bunga terompet ungu sebagai berikut :

1) Sampel makanan diletakkan diulekan kemudian dihancurkan sampai halus dan ditambahkan satu sendok teh air.

2) Setiap sampel makanan (cilok, sosis, mie) ditaruh di rongga palet yang berbeda-beda

3) Berikan label nama untuk menandai makanan apa saja yang diujikan untuk memudahkan identifikasi makanan 
4) Beberapa bunga terompet ungu (dua buah) letakkan diulekan kemudian dihancurkan sampai halus dan ditambahkan dua sendok teh air.

5) Ambil beberapa tetes cairan ekstrak bunga terompet ungu dan kemudian teteskan pada masing-masing sampel makanan.

6) Amati perubahan warna pada sampel makanan. Apabila makanan positif mengandung boraks maka warnanya akan berubah menjadi hijau karena $\mathrm{pH}$ boraks sekitar 9-11. Sedangkan jika makanan positif mengandung formalin, maka warnanya akan berubah menjadi coklat-kemerahan karena $\mathrm{pH}$ formalin sekitar 5-6. Sementara makanan yang bebas formalin dan boraks akan tetap berwarna ungu seperti warna asli ekstrak bunga atau tidak mengalami perubahan warna. Perubahan warna yang terjadi sangat singkat hanya 2-3 menit sudah bisa terlihat hasilnya.

d. Evaluasi dilakukan dengan Peserta diminta mempraktekan kembali cara deteksi sederhana boraks dan formalin pada makanan jajanan anak dengan menggunakan bunga terompet ungu.

\section{HASIL}

Hasil kegiatan pengabmas yang dilakukan di aula kantor kelurahan Desa Trunuh Kecamatan Klaten Selatan Kabupaten Klaten adalah sebagai berikut:

a. Penyuluhan kesehatan

Sebelum memmberikan penyuluhan kesehatan peserta diberi pertanyaan secara lisan secara terstruktur untuk melihat sejauhmana pemahaman tentang bahan tambahan kimia pada makanan yang dilarang, bahaya, dampak dan cara untuk mendeteksi sederhana kandungan boraks dan formalin pada makanan janjanan anak dengan bunga terompet ungu. Pertanyaan dipersiapkan oleh tim pengabmas secara terstruktur. Hasil awal didapatkan bahwa rata-rata peserta dapat menjawab 50\% dari pertanyaan yang diberikan. Langkah selanjutnya adalah pemberian penyuluhan kesehatan, yang bertujuan untuk meningkatkan pengetahuan bahan tambahan kimia pada makanan yang dilarang, bahaya, dampak dan cara untuk mendeteksi sederhana kandungan boraks dan formalin pada makanan janjanan anak dengan bunga terompet ungu. Peserta yang hadir sangat bersemangat dan aktif bertanya tentang materi yang disampaikan. Evaluasi penyuluhan kesehatan dilakukan dengan cara yang sama seperti di awal penyuluhan, dengan memberikan pertanyaan lisan kepada peserta. Hasil evaluasi setelah pelakasanaan penyuluhan peserta $90 \%$ dapat menjawab pertanyaan dengan tepat dan dapat menjelaskan kembali tentang bahan tambahan kimia pada makanan yang dilarang, bahaya, dampak dan cara untuk mendeteksi sederhana kandungan boraks dan formalin pada makanan janjanan anak dengan bunga terompet ungu.

b. Deteksi sederhana kandungan boraks dan formalin pada makanan janjanan anak dengan bunga terompet ungu Pelaksanaan pelatihan deteksi sederhana kandungan boraks dan formalin pada makanan janjanan anak dengan bunga terompet ungu terapi SEFT dilakukan dengan cara demonstrasi dan redemonstrasi langkah demi langkah sesuai SOP yang sudah ada di dalam booklet. Untuk melihat keberhasilan deteksi sederhana kandungan boraks dan formalin pada makanan janjanan anak 
dengan bunga terompet ungu, peserta dilakukan evaluasi dengan cara peserta diminta mempraktekkan cara deteksi sederhana kandungan boraks dan formalin pada makanan janjanan anak dengan bunga terompet ungu dengan observasi dengan menggunakan kuesioner penilaian pelaksanaan deteksi sederhana kandungan boraks dan formalin pada makanan janjanan anak dengan bunga terompet ungu. Berdasarkan hasil observasi, $90 \%$ peserta dapat melakukan deteksi sederhana kandungan boraks dan formalin pada makanan janjanan anak dengan bunga terompet ungu.

\section{PEMBAHASAN}

Pendeteksian terhadap adanya kandungan formalin dan boraks pada makanana jajanan anak adalah dengan cara menyediakan alat deteksi sederhana dari bunga terompet ungu.

Konsumsi formalin dalam jangka panjang menyebabkan iritasi membran mukosa, radang kulit merangsang SPP, apatis, depresi, slanosis, pingsan, kebodohan dan bersifat racun (karsinogenik) (Walefield, 2014), konsumsi boraks secara kronis mengganggu kontraksi pencernaan usus, gangguan pada susunan saraf, depresi, dan kekacauan mental (Saparinto, 2005).

Penelitian oleh Erniati (2017) bahwa berdasarkan uji laboratorium sampel bakso yang dijual di SD N Lemahputro III Sidoarjo, mayoritas positif mengandung boraks. Hal ini disebabkan pedagang bakso sebagian kurang mengetahui tentang pengertian, manfaat, dosis boraks yang diijinkan dan dampak dari boraks.

Indikator merupakan bahan kimia yang mengubah warna larutan dengan perubahan $\mathrm{pH}$ setelah ditambahkan basa atau asam (Gupta, 2012). Indikator asam basa yang digunakan di laboratorium kimia adalah indicator sintesis, indicator sintesis memiliki karakteristik berupa trayek $\mathrm{pH}$ yang ditunjukkan dengan perubahan warna pada kondisi asam dan basa serta harga tetapan indikator, indicator sintesis yang terbatas menyebabkan pemakaianya dibatasi, selain itu, indicator sintesis harganya cukup mahal, serta menyebabkan polusi lingkungan (Nuryanti, dkk, 2010). Karena hal tersebut perlu dicari indicator alternatif (indicator alami) yang mudah diperoleh dan ramah lingkungan.

Indikator alamiah dapat dibuat dari berbagai tumbuhan berwarna yang berada disekitar lingkungan untuk deteksi borak dan formalin, namun tidak semua tumbuhan berwarna dapat memberikan perubahan warna yang jelas pada kondisi asam atau basa, contoh tumbuhan yang dapat digunakan adalah bunga teropet ungu (Ruellia Tuberosa) yang dapat memberikan perubahan pada suasana asam warna merah dan hijau pada suasana basa hal ini dikarenakan antara bunga teropet ungu terdapat senyawa yang memberikan warna pada tumbuhan, yakni sebagai antosianin. Antosianin dapat digunakan pendeteksi adanya senyawa kimia seperti boraks dan formalin karena sifat asam basa dan akan bereaksi jika dicampur dengan antosianin (Nuryanti, dkk, 2010).

Bunga teropet ungu (Ruellia Tuberosa) sangat mudah ditemukan diberbagai tempat, dipinggir jalan dan harga murah, umumnya hanya digunakan sebagai tanaman hias dan tanaman peneduh serta belum termanfaatkan secara maksimal. 
Tanaman bunga yang berasal dari Meksiko, Karibia dan Amerika Selatan ini memiliki kandungan pigmen antosianin. Zat antosianin ini yang memberikan warna ungu pada bunga ruellia. Penelitian memanfaatkan zat antosianin yang sensitif terhadap derajat keasaman $(\mathrm{pH})$ lingkungan yang ditandai dengan perubahan warna. Pada dasarnya antosianin yang terdapat pada bunga ruellia memiliki penanda warna: merah untuk $\mathrm{pH}$ 1-3, coklat-kemerahan untuk $\mathrm{pH}$ 5-6, coklat-kehijauan untuk pH 7-8, hijau untuk pH 9-11 dan kuning untuk pH 13-14 (Dina M, 2019).

\section{KESIMPULAN DAN SARAN}

\subsection{Kesimpulan}

Kesimpulan dari hasil kegiatan pengabdian pada masyarakat ini adalah Ibu dengan usia anak sekolah dapat melakukan deteksi sederhana pada makanan jajanan anak dengan menggunakan bunga terompet ungu sebanyak $90 \%$.

\subsection{Saran}

Bunga teropet ungu (Ruellia Tuberosa) sangat mudah ditemukan diberbagai tempat, dipinggir jalan dan harga murah dapat dijadikan sebagai salah satu alternatif almaih untuk deteksi sederhana makanan jajanan anak yang mengandung boraks dan formalin yang membahayakan bagi tubuh.

\section{UCAPAN TERIMAKASIH}

Terimakasih kami ucapkan kepada Direktur dan Ka Unit Penelitian dan Pengabmas Poltekkes Kemenkes Surakarta atas support untuk terselenggaranya Pengabmas ini.

\section{DAFTAR RUJUKAN}

Aprilia, B.A. (2011). Faktor Yang Berhubungan dengan Pemilihan Makanan Jajanan Pada Anak Sekolah Dasar [Skripsi]. Universitas Diponegoro. Semarang.

BPOM Republik Indonesia, (2008). Kamanan Pangan Jajanan Anak Sekolah (PJAS) Serta Upaya Penanggulangannya. Badan Pengawas Obat dan Makanan. Jakarta. Vol. 9, No. 6.

BPOM RI. (2014) Laporan Tahunan 2014. Jakarta.

Manafe D. 2019. Bunga Reullia Cara Mudah Deteks Boraks dan Formalin. https://www.beritasatu.com/kesehatan/573466-bunga-reullia-cara-mudahdeteksi-boraks-dan-formalin. diunduh tanggal 28 Januari 2020.

Diyantini, N. K., Yanti, N. L. P. E., \& Lismawati, S. M. (2015). Hubungan Karakteristik dan Kepribadian Anak dengan Kejadian Bullying pada Siswa Kelas $V$ di SD " $X$ " di Kabupaten (Badung. COPING (Community of Publishing in Nursing). 
Erniati. (2017). Tingkat pendidikan, Pengetahuan, Sikap Pedagang Bakso dan Penggunaan Boraks pada Boraks di SDN Lemahputro Sidoarjo. Jurnal Kesehatan Lingkungan. 9(2), 209-216.

Gupta, P., Jain, P. dan Jain, P.K. 2012. Isolation Of Natural Acid Base Indikator From The Flower Sap Of Hibiscus rosasinensis. Journal of Chemical And Pharmaceutical Research. Vol.4, No.12, Hal.4957-4960.

Hartati Fadjar. K. 2017. Analisis boraks secara cepat, mudah, dan murah pada kerupuk. Universitas Dr. Soetomo. Surabaya

Yhona Paratmanitta, Veriani A, 2016. Kandungan bahan tambahan pangan berbahaya pada makanan jajanan anak sekolah dasar di Kabupaten Bantul. Jurnal Gizi dan Dietetik Indonesia. Vol. 4, No.1, 49-55.

Nasution, A. (2009). Analisa Kandungan Boraks pada Lontong di Kelurahan Padang Bulan Kota Makassar. [Skripsi]. Universitas Sumatera Utara. Medan.

Noval Kurniadi, 2019. Bunga Reullia untuk Deteksi Boraks dan Formalin pada jajanan anak. https://kumparan.com/noval-kurniadi/bunga-ruellia-untukdeteksi-boraks-dan-formalin-pada-jajanan-anak-1rnErktvS85. diunduh tanggal 28 Januari 2020.

Nuryanti, S., Matsjeh, S., Anwar, C. danRaharjo, T. J. 2010. Indikator Titrasi Asambasa dari Ekstrak Bunga Sepatu. Agritech..Universitas Gajah Mada, Yogyakarta. Vol. 30, No. 3.

Paratmanitya, dkk. (2016). Kandungan Bahan Tambahan Pangan Berbahaya Pada Makanan Jajanan Anak Sekolah Dasar di Kabupaten Bantul. Jurnal gizi dan dietetic. Vol. 4 No.1.

Saparinto C, Diana H. 2006. Bahan tambahan pangan. Kanisius. Yogyakarta.

Suhariyadi, Setianingrum, R., Prastyo, F.A., $\quad \& \quad$ Christyaningsih, $\quad$ J. (2015). Survey on the Use of Borax, Magenta and Metanyl Yellow in Food Samples Procured from State Elemntary Schools of Surabaya City. Research Journal of Pharmaceutical, Biological and Chemical Sciences. 6(1), 1587-1592.

Tubagus, I, Gayatri, C, Fatimawali. 2013. Identifikasi dan Penetapan Kadar Boraks Dalam Bakso Jajanan di Kota Manado. Man ado. 
Wakefield J. Formaldehyde, toxicological overview [Internet]. (2008). [cited 2014 Apr 16]. Available from: http://www.hpa.org.uk/webc/ hpawebfile/hpaweb_c/1219908739327.

Widyaningsih, T.W, dan E.S. Murtini. (2006). Alternatif Pengganti Formalin Pada Produk Pangan. Trubus Agirasana, Surabaya. 